\title{
Pengembangan Media Pembelajaran Interaktif Dengan Pendekatan Kontekstual Pada Materi Bentuk Aljabar
}

\author{
Rifda Ulfa Mukhtar ${ }^{1}$, Maimunah ${ }^{2}$, Putri Yuanita ${ }^{3}$ \\ 1, 2, 3 Program Studi Pendidikan Matematika, Fakultas Keguruan dan Ilmu Pendidikan, Universitas Riau \\ Jl. Bina Widya Simpang Baru, Pekanbaru \\ rifdaulfa@gmail.com
}

\begin{abstract}
This research is research on the development of interactive learning media that can be used by students through smartphones with a contextual approach to algebraic material for junior high school students. The purpose of this research is to produce interactive learning media with a contextual approach to valid and practical. This study uses a 4D development model which consists of four stages, namely define, design, develop and disseminate. The types of data in this study are qualitative and quantitative data. The expert test carried out in this study was to provide an assessment of the media and material components. Learning media obtained very valid criteria with a score of 4.3 and 4.4. This shows that the learning media is able to carry out its measuring function by following the planned objectives and is suitable for use in trial activities. In the trial activity, the learning media got very practical criteria with a score of 4.3 which indicates that the learning media can be used well by users.
\end{abstract}

Keywords: Contextual Approach, Interactive, Learning Media

\begin{abstract}
Abstrak
Penelitian ini merupakan penelitian pengembangan media pembelajaran interaktif yang dapat digunakan siswa melalui smartphone dengan pendekatan kontekstual materi bentuk aljabar untuk siswa SMP. Tujuan penelitian ini adalah menghasilkan media pembelajaran interaktif dengan pendekatan kontekstual yang valid dan praktis. Penelitian ini menggunakan model pengembangan 4D yang terdiri dari empat tahap yaitu define, design, develop dan disseminate. Jenis data dalam penelitian ini adalah data kualitatif dan kuantitatif. Uji ahli yang dilakukan dalam penelitian ini adalah memberikan penilaian terhadap komponen media dan materi. Media pembelajaran memperoleh kriteria sangat valid dengan skor 4,3 dan 4,4. Ini menunjukkan bahwa media pembelajaran mampu melakukan fungsi ukurnya sesuai dengan tujuan yang direncanakan dan layak untuk digunakan dalam kegiatan uji coba. Pada kegiatan uji coba, media pembelajaran mendapatkan kriteria sangat praktis dengan skor 4,3 yang menunjukkan bahwa media pembelajaran dapat digunakan dengan baik oleh pengguna.
\end{abstract}

Kata kunci: Pendekatan Kontekstual, Interaktif, Media Pembelajaran

Copyright (c) 2022 Rifda Ulfa Mukhtar, Maimunah, Putri Yuanita

$\triangle$ Corresponding author: Rifda Ulfa Mukhtar

Email Address: rifdaulfa@gmail.com (Jl. Kubang Raya 45, Pekanbaru)

Received 27 October 2021, Accepted 14 December 2021, Published 14 February 2022

\section{PENDAHULUAN}

Kemampuan dalam menggunakan smartphone saat ini hampir dimiliki oleh setiap siswa, berdasarkan hasil survey (KOMINFO, 2017) menunjukkan bahwa 70,98\% pelajar/mahasiswa di Indonseia sudah memiliki smartphone. Hasil survey yang sama diperoleh informasi yaitu individu memanfaatkan smartphonenya ketika tidak terhubung dengan internet untuk komunikasi 95,68\%, hiburan $41,06 \%$, bekerja $17,52 \%$ dan belajar $13,97 \%$. Selanjutnya, penggunaan smartphone ketika terhubung dengan internet untuk komunikasi $93,46 \%$, hiburan $65,29 \%$, browsing $76,88 \%$, belajar $27,51 \%$ dan bekerja $25,70 \%$. Berdasarkan kedua hasil survey tersebut dapat disimpulkan bahwa pemanfaatan smartphone dalam kegiatan pembelajaran masih kurang. Pada era perkembangan 
teknologi dan informasi ini, pemanfaat samrtphone dalam kegiatan belajar sangat tepat. Salah satu contohnya adalah media pembelajaran yang dapat diakses menggunakan smartphone.

Media pembelajaran merupakan segala sesuatu yang mampu menyampaikan atau menyalurkan informasi secara efektif dan efisien dalam kegiatan pembelajaran (Istiqlal, 2017). Pemilihan media pembelajaran yang tepat dalam proses pembelajaran dapat memberikan pengaruh positif yang dapat dilihat dari hasil belajar dan meningkatnya motivasi belajar siswa. Media pembelajaran interaktif sangat tepat digunakan untuk kegiatan pembelajaran, dimana pada media pembelajaran interaktif siswa dituntut untuk terlibat aktif dalam kegiatan pembelajaran. Interaktif dalam lingkup media pembelajaran bukan terletak pada sistem hardware, tetapi lebih mengacu pada karakteristik belajar siswa dalam merespon stimulus yang disampaikan layar monitor (Istiqlal, 2017).

Pemanfaatan media pembelajaran interaktif dalam kegiatan pembelajaran menyebabkan siswa dituntut untuk aktif dalam merespon materi ataupun pertanyaan yang disampaikan dalam media pembelajaran dan media pembelajaran akan memberikan respon kembali kepada siswa agar dapat saling berinteraksi. Hasil penelitian oleh Handayani dan Rahayu (2020) menunjukkan bahwa media interaktif yang dikembangkan memiliki manfaat yang besar khususnya dalam memahami materi. Karuniakhalida et al., (2019) dalam penelitiannya mengembangkan media pembelajaran berbasis ICT menunjukkan bahwa media secara efektif meningkatkan motivasi belajar siswa. Selanjutnya, Aulia (2014) menyebutkan bahwa media pembelajaran interaktif yang telah dikembangkan mampu meningkatkan hasil belajar siswa. Oleh karena itu, penggunaan media pembelajaran interaktif adalah hal yang cukup penting dalam kegiatan pembelajaran.

Dalam mengembangkan media pembelajaran interaktif ini perlu diterapkan pendekatan pembelajaran agar siswa dapat dengan mudah memahami materi yang terdapat didalam media pembelajaran interaktif ini. Pendekatan pembelajaran yang tepat agar dapat melibatkan siswa secara aktif memperoleh pengalaman belajar adalah pendekatan kontekstual. Dalam beberapa penelitian terdahulu yaitu Retnasari et al., (2016), Fathir, (2015), dan Nuraisah et al., (2016) menunjukkan bahwa pendekatan kontekstual dapat meningkatkan motivasi belajar siswa secara signifikan.

Pembelajaran kontekstual merupakan pendekatan pembelajaran yang membantu guru mengaitkan antara materi yang diajarkan dengan situasi dunia nyata siswa dan mendorong siswa membuat hubungan antara pengetahuan yang dimilikinya dengan penerapannya dalam kehidupan mereka sebagai anggota keluarga dan masyarakat, serta pengetahuan yang diperoleh dari usaha siswa mengkonstruksi sendiri pengetahuan dan keterampilan baru ketika ia belajar (Saefuddin dan Berdiati, 2016). Dengan demikian, pembelajaran kontekstual yang mengaitkan pembelajaran dengan situasi dunia nyata ini akan membuat siswa lebih sadar tentang pentingnya pembelajaran matematika dalam kehidupan mereka. Terdapat 7 komponen penting dari pendekatan kontekstual menurut Saefuddin dan Berdiati (2016) yaitu kontruktivisme, inkuiri, questioning, learning community, modeling, reflection dan authentic assesment.

Berdasarkan permasalahan bahwa masih rendahnya pemanfaatan smarthphone untuk kegiatan 
pembelajaran yaitu hanya $27,51 \%$. Maka peneliti mengembangkan media pembelajaran yang dapat digunakan melalui smartphone dengan menrapkan pendekatan kontekstual. Pada kegiatan pembelajaran disekolah khususnya pada jenjang sekolah menengah pertama (SMP), penggunaan smartphone disekolah belum dianjurkan disetiap sekolah. Untuk mengatasi hal ini, maka peneliti mengembangkan media pembelajaran ini agar dapat juga digunakan melalui komputer. Pembuatan media pembelajaran interaktif dengan pendekatan kontekstual menggunakan aplikasi utama yaitu $M s$. Power Point yang di ekspor ke dalam format HTML menggunakan aplikasi I-Spring dan selanjutnya di konversi menjadi aplikasi smartphone menggunakan aplikasi APK Builder.

Penelitian terdahulu mengenai pengembangan media pembelajaran menggunakan aplikasi $I$ Spring sudah pernah dilakukan, diantaranya yaitu penelitian oleh Handayani \& Rahayu, (2020) yang menunjukkan bahwa media pembelajaran yang dikembangkan memberikan manfaat yang besar khususnya dalam pemahaman materi. Namun, dalam penelitiannya Media pembelajaran yang dikembangkan tidak menerapkan pendekatan pembelajaran matematika, oleh karena itu peneliti mengembangkan media pembelajaran dengan pendekatan kontekstual agar kegiatan belajar lebih dekat dengan siswa. Tujuan dari penelitian ini adalah untuk menghasilkan media pembelajaran interaktif dengan pendekatan kontekstual pada materi bentuk aljabar yang telah valid dan praktis.

\section{METODE}

Dalam penelitian ini digunakan model Thiagarajan atau lebih dikenal dengan 4D. Sugiyono (2019) menjelaskan tentang setiap tahap 4D sebagai berikut: Define (pendefinisian), berisi kegiatan untuk menetapkan produk apa yang dikembangkan, beserta spesifikasinya. Design (perancangan), berisi kegiatan untuk membuat rancangan terhadap produk yang telah ditetapkan. Development (pengembangan) berisi kegiatan membuat rancangan menjadi produk dan menguji validitas produk secara berulang-ulang sampai dihasilkan produk yang sesuai dengan spesifikasi yang ditetapkan. Dissemination (diseminasi) berisi kegiatan menyebarluaskan produk yang telah teruji untuk dimanfaatkan orang lain.

Penelitian ini dimulai pada bulan November 2020 hingga Juli 2021. Pada penelitian pengembangan ini tahap define melalui tiga tahap, yaitu analisis awal-akhir, analisis siswa, dan analisis konsep. Pada tahap design terdapat tiga langkah yaitu pemilihan media, pemilihan format dan rancangan awal. Pada tahap develop terdiri dari kegiatan uji ahli dan uji coba one to one dengan tujuan untuk menghasilkan media pembelajaran yang sudah direvisi berdasarkan masukan dari para pakar dan revisi dari kegiatan uji coba. Tahap disseminate merupakan tahap untuk menyebarluaskan hasil akhir dari produk.

Jenis data dalam penelitian pengembangan ini adalah data kualitatif dan data kuantitatif. Data kualitatif berupa pernyataan deskripsi baik masukan, tanggapan, dan kritik selama kegiatan pengembangan media pembelajaran interaktif dengan pendekatan kontekstual pada materi bentuk aljabar yang diperoleh dari validator, guru dan siswa. Data kuantitatif berupa angka-angka yang 
memiliki nilai dan diperoleh dari lembar penilaian dan angket selama kegiatan pengembangan media pembelajaran interaktif dengan pendekatan kontekstual pada materi bentuk aljabar.

Instrumen pengumpulan data dalam penelitian ini menggunakan lembar validasi dan angket respon siswa. Lembar validasi media pembelajaran interaktif dengan pendekatan kontekstual pada materi bentuk aljabar yang digunakan adalah lembar validasi media dan lembar validasi materi dan diisi oleh validator kemudian dianalisis. Teknik analisis data untuk kevalidan media pembelajaran dilakukan secara deskriptif. Hasil validasi ahli berupa penilaian skala lima yaitu 1 = sangat tidak setuju, 2 = tidak setuju, 3 = ragu-ragu, 4 = setuju, dan $5=$ sangat setuju.

Dalam penelitian ini kevalidan media pembelajaran ditentukan dengan minimal memperoleh kriteria valid. Apabila cukup valid maka dilakukan revisi sehingga media pembelajaran menjadi valid dengan revisi berdasarkan saran dan masukan dari ahli. Apabila media pembelajaran kurang valid sangat kurang valid maka dilakukan proses revisi, kemudian dilakukan validasi ulang untuk menguji kualitas produk (Zakirman \& Hidayati, 2017).

Analisis kepraktisan dilakukan pada uji coba kelas one to one. Analisis kepraktisan dilakukan dengan menganalisis angket respon siswa yang menjawab pada rentang penilaian sekala lima yaitu 1 = sangat tidak setuju, 2 = tidak setuju, 3 = ragu-ragu, 4 = setuju dan 5 = sangat setuju. Penilaian siswa terhadap media pembelajaran dikatakan praktis apabila memenuhi kategori minimal praktis. Hasil penilaian dianalisis kemudian disimpulkan apakah perangkat telah memenuhi kriteria praktis. Apabila pada analisis kepraktisan masih diperoleh kriteria kurang praktis maka dilakukan revisi sehingga media pembelajaran menjadi praktis dengan revisi.

\section{HASIL DAN DISKUSI}

Produk yang dihasilkan pada penelitian ini adalah media pembelajaran interaktif dengan pendekatan kontekstual untuk memfasilitasi motivasi belajar siswa melalui tahap 4D. Setiap kegiatan pada setiap tahap dapat dilihat sebagai berikut:

\section{Define (Pendefinisian)}

Pada tahap analisis awal akhir, diketahui bahwa masih terdapat beberapa kendala dalam kegiatan pembelajaran disekolah. Setelah dilakukan wawancara dibeberapa sekolah, diketahui bahwa hasil belajara matematika siswa masih rendah. Salah satu hasil wawancara peneliti dengan guru dapat dilihat pada tabel 1 berikut.

Tabel 1. Hasil Wawancara dengan Guru

\begin{tabular}{|c|l|l|}
\hline No & \multicolumn{1}{|c|}{ Pertanyaan } & \multicolumn{1}{c|}{ Jawaban } \\
\hline 1 & $\begin{array}{l}\text { Apakah masih terdapat } \\
\text { kendala dalam kegiatan } \\
\text { pembelajaran mateatika saat } \\
\text { ini? }\end{array}$ & $\begin{array}{l}\text { Masih tapi tidak berlaku secara umum. } \\
\text { Maksudnya adalah ada beberapa siswa yang } \\
\text { belum memahami beberapa materi tertentu yang } \\
\text { berpengaruh untuk materi berikutnya. }\end{array}$ \\
\hline 2 & $\begin{array}{l}\text { Menurut ibu/bapak materi apa } \\
\text { yang sangat penting dipahami } \\
\text { siswa agar kegiatan } \\
\text { pembelajaran matematika }\end{array}$ & $\begin{array}{l}\text { Semua materi penting, dan salah satunya adalah } \\
\text { materi operasi bentuk aljabar. Ini penting karena } \\
\text { konsep penjumlahan, pengurangan, perkalian dan } \\
\text { merasionalkan bentuk aljabar ini akan sering }\end{array}$ \\
\hline
\end{tabular}




\begin{tabular}{|c|l|l|}
\hline & berjalan baik? & digunakan dimateri lain. \\
\hline 3 & $\begin{array}{l}\text { Selama kegiatan pembelajaran } \\
\text { apakah ibu/bapak } \\
\text { menggunakan media } \\
\text { pembelajaran? }\end{array}$ & Untuk beberapa materi saya menggunakannya. \\
\hline 4 & $\begin{array}{l}\text { Apa kelebihan dan } \\
\text { kekurangan dari media } \\
\text { pembelajaran yang saat ini } \\
\text { digunakan? }\end{array}$ & $\begin{array}{l}\text { Ketika saya menyampaikan materi menggunakan } \\
\text { power point, pada awal pembelajaran siswa } \\
\text { terlihat tertarik dan aktif mengikuti kegiatan } \\
\text { pembelajaran. Namun, ada pada suatu saat siswa } \\
\text { mulai merasa jenuh dengan hanya melihat layar } \\
\text { infocus. Begitu juga dengan video pembelajaran. }\end{array}$ \\
\hline 5 & $\begin{array}{l}\text { Menurut ibu/bapak apakah } \\
\text { perlu dikembangkan media } \\
\text { pembelajaran interaktif pada } \\
\text { saat ini? }\end{array}$ & $\begin{array}{l}\text { Perlu, karena media interaktif mengharuskan } \\
\text { siswa ikut berpartisipasi ketika belajar jadi ini } \\
\text { diharapkan dapat menguruangi rasa bosan siswa. }\end{array}$ \\
\hline
\end{tabular}

Pada Tabel 1, diketahui bahwa salah satu materi yang penting dipahami oleh siswa adalah materi bentuk aljabar. Pemahaman materi bentuk aljabar diterapkan dalam banyak materi setelahnya salah satunya adalah SPLDV, SPtLD, Pythagoras dan lain sebagainya. Selanjutnya, media pembelajaran yang sering digunakan hanyalah power point berupa materi dan video pembelajaran yang ditampilkan menggunakan infocus. Hal ini juga disampaikan oleh Abdullah (2017) dalam hasil penelitiannya yaitu guru belum menggunakan media yang bervariasi dalam pembelajaran terutama media yang berbentuk elektronik. Hal tersebut sering membuat siswa lebih cepat merasa bosan karena tidak terlibat aktif dan hanya mendengarkan penjelasan dari guru. Ini menunjukkan bahwa penggunaan media pembelajaran interaktif masih jarang.

Pada tahap analisis siswa, peneliti melakukan kajian hasil penelitian dan teori untuk melihat kendala yang dialami siswa dalam pembelajaran matematika. Hasil penelitian oleh Hasibuan (2015) diketahui bahwa salah satu penyebab kesulitan yang dialami siswa dalam mempelajari materi aljabar adalah karena pemahaman dasar yang rendah tentang materi prasyarat aljabar, kurangnya minat/kemauan dalam mempelajari bentuk alajabar dan kurangnya latihan mengerjakan soal serta pembelajaran materi bentuk aljabar kurang bermakna. Herutomo (2017) mengatakan bahwa kendala yang terjadi dalam kegiatan pembelajaran materi bentuk aljabar adalah miskonsepsi salah satunya yaitu kurang memahami konsep variabel sebagai sesuatu yang belum diketahui dan menggunakan cara menebak untuk menyelesaikan soal soal SPLDV.

Selanjutnya, Dwi Kusumawati \& Sutriyono, (2018) diketahui bahwa faktor yang menyebabkan kesulitan belajar dalam materi bentuk aljabar yaitu 1) motivasi siswa dalam pembelajaran yang cenderung rendah; 2) penggunaan alat peraga dari guru yang belum optimal. Dari uraian tersebut dapat disimpulkan bahwa kendala yang dialami siswa dalam pembelajaran materi bentuk alajabar adalah: Pemahamanan dasar bentuk aljabar yang masih rendah, pembelajaran bentuk aljabar yang kurang bermakna, adanya miskonsepsi materi,kurangnya latihan soal dan motivasi belajar siswa yang cenderung rendah. 
Pada tahap analisis konsep dilakukan analisis kurikulum dan diperoleh susunan materi bentuk aljabar yang akan diterapkan pada media pembelajaran. Berdasarkan Permendikbud No. 37 tahun 2018 materi operasi hitung bentuk aljabar berada pada kelas VII SMP/MTs yaitu KD 3.5 menjelaskan bentuk aljabar dan melakukan operasi pada bentuk aljabar (penjumlahan, pengurangan, perkalian dan pembagian), KD 4.5 menyelesaikan masalah yang berkaitan dengan bentuk aljabar dan operasi pada bentuk aljabar. Susunan materi bentuk aljabar dan indikator dapat dilihat pada tabel 2.

Tabel 2. Susunan Materi dan Indikator

\begin{tabular}{|c|c|c|}
\hline Kompetensi dasar & Materi & Indikator \\
\hline $\begin{array}{l}3.5 \text { Menjelaskan bentuk } \\
\text { aljabar dan melakukan } \\
\text { operasi pada bentuk aljabar } \\
\text { (penjumlahan, pengurangan, } \\
\text { perkalian dan pembagian) }\end{array}$ & \multirow[t]{2}{*}{$\begin{array}{l}\text { - Mengenal } \\
\text { bentuk aljabar } \\
\text { - Penjumlahan } \\
\text { dan } \\
\text { Pengurangan } \\
\text { Bentuk aljabar } \\
\text { - Perkalian } \\
\text { Bentuk Aljabar } \\
\text { - Pembagian } \\
\text { Bentuk Aljabar }\end{array}$} & 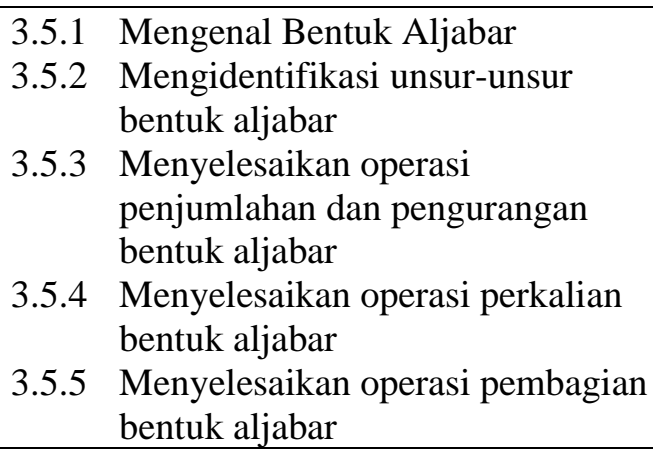 \\
\hline $\begin{array}{l}4.5 \text { Menyelesaikan masalah } \\
\text { yang berkaitan dengan } \\
\text { bentuk aljabar dan operasi } \\
\text { pada bentuk aljabar }\end{array}$ & & $\begin{array}{l}\text { 4.5.1. } \begin{array}{l}\text { Menyelesaikan bentuk aljabar } \\
\text { dalam masalah nyata }\end{array} \\
\text { 4.5.2. } \begin{array}{l}\text { Menyelesaikan masalah } \\
\text { kontesktual pada operasi bentuk } \\
\text { aljabar }\end{array}\end{array}$ \\
\hline
\end{tabular}

\section{Design (Perancangan)}

Media yang dipilih dalam penelitian ini untuk merancang media pembelajaran interaktif adalah aplikasi Ms. Power Point, I-Spring dan Apk Builder. Media pembelajaran akan dirancang menggunakan aplikasi utama yaitu Ms. Power Point. Roza et al. (2017) mengatakan bahwa "These applications provide everything needed to create this learning media application" aplikasi ini memberikan semua yang dibutuhkan untuk mebuat aplikasi media pembelajaran. Selanjutnya format power point akan di ekspor ke dalam format HTML5 menggunakan aplikasi I-Spring dan selanjutnya di konversi menjadi aplikasi smartphone menggunakan aplikasi APK Builder. Handayani \& Rahayu, (2020) mengatakan bahwa pemilihan Ms. Power Point yang diupgrade melalui I-Spring dan APK Builder dalam penelitian pengembangan media pembelajaran memiliki beberapa kelebihan diantaranya mudah dan dapat diulang penggunaannya.

Format yang digunakan dalam media pembelajaran ini adalah sebagai berikut : Jenis huruf yang digunakan Cambria Math ukuran 12-20, Spasi antar baris 1,5, Menggunakan beberapa gambar, animasi dan video, Disajikan tombol navigasi : home, next dan preview, Penyusunan materi diorganisasikan secara sistematis dan berurutan.

Dalam $C D$ (compact disk) media pembelajaran interaktif terdapat 4 komponen, yaitu folder media pembelajaran format HTML yang didalamannya terdapat 5 kegiatan belajar, folder media 
pembelajaran berupa aplikasi andorid yang didalamannya terdapat 4 kegiatan belajar, file petunjuk penggunaan media, file pengenalan karakter dan file identitas penulis. Berikut beberapa tampilan dari hasil rancangan awal media pembelajaran interaktif yang telah dikembangkan dengan menggunakan 7 komponen pendekatan kontekstual menurut:

Komponen kontruktivisme disajikan pada slide dimana siswa diminta untuk memahami masalah yang diberikan, seperti pada gambar 1 berikut.

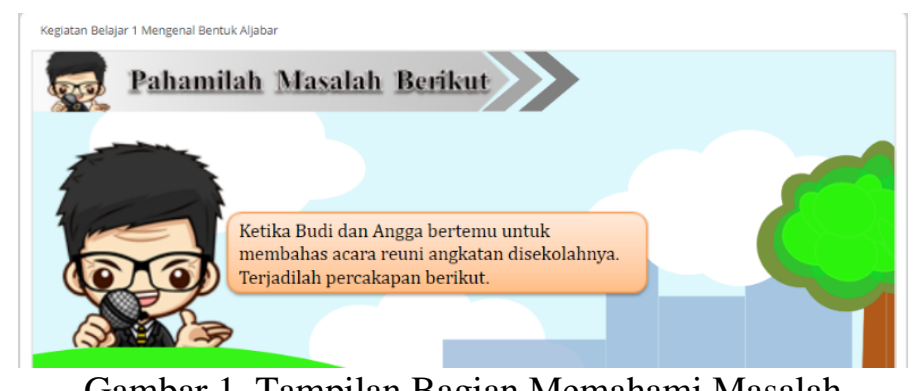

Gambar 1. Tampilan Bagian Memahami Masalah

Komponen inkuiri disajikan pada slide dimana siswa diminta untuk mengamati proses penemuan konsep bentuk aljabar, kegiatan ini dapat dilihat pada gambar 2 berikut

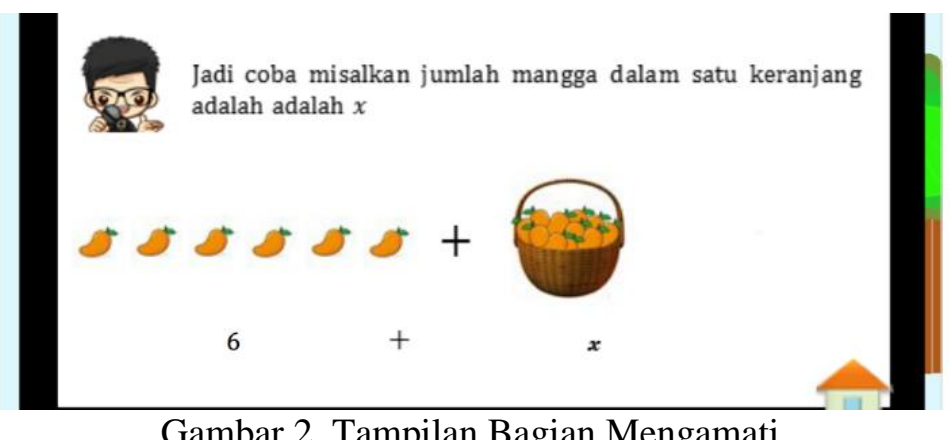

Gambar 2. Tampilan Bagian Mengamati

Komponen questioning dimana terdapat pertanyaan yang mendorong siswa untuk berpikir bagaimana cara mengetahui jumlah mangga yang terdapat didalam keranjang, kegiatan ini dapat dilihat pada gambar 3 berikut.

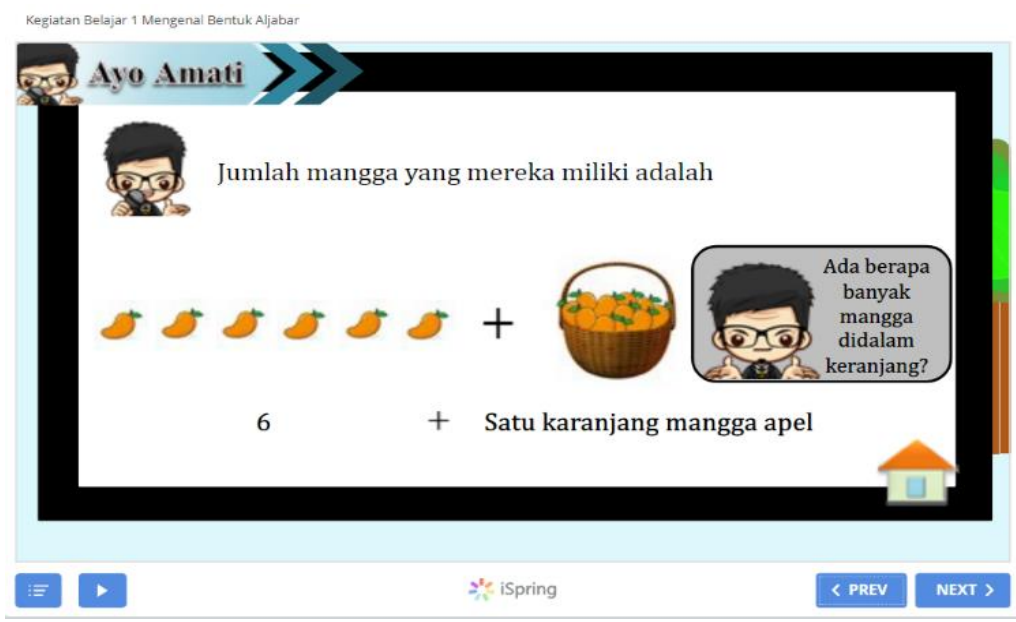

Gambar 3. Tampilan Bagian Pertanyaan 
Komponen learning community, komponen ini diberikan setelah materi pada setiap kegiatan belajar telah selesai. Dimana nantinya pada slide ini siswa diminta untuk berkerjasama dalam menjawab sebuah pertanyaan seperti pada gambar 4 berikut

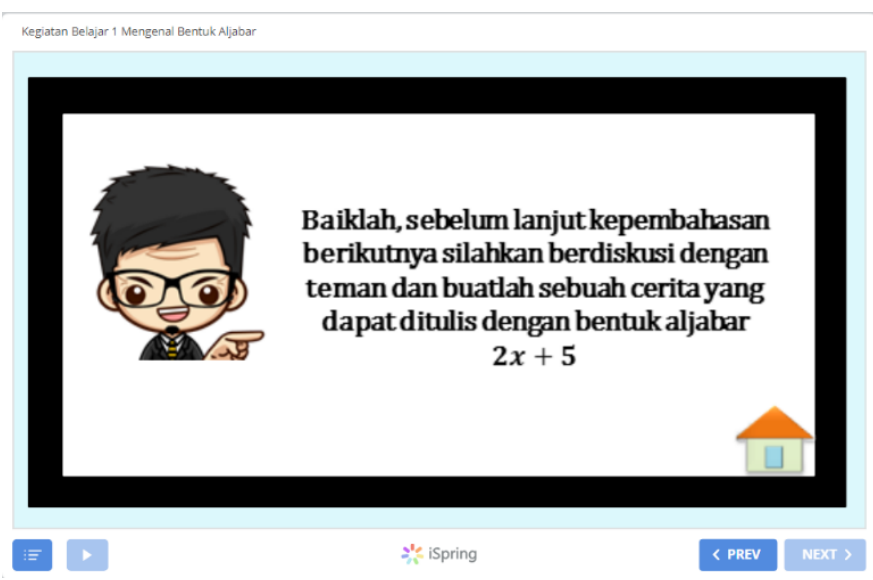

Gambar 4. Tampilan Halaman Bekerjasama

Komponen modeling pada bagian ini siswa diberikan beberapa contoh sehingga siswa mampu mengerjakan sebuah soal sesuai dengan yang dicontohkan. Setiap kegiatan pembelajaran terdapat contoh sebelum mengerjakan tugas yang diberikan seperti pada gambar 5 berikut

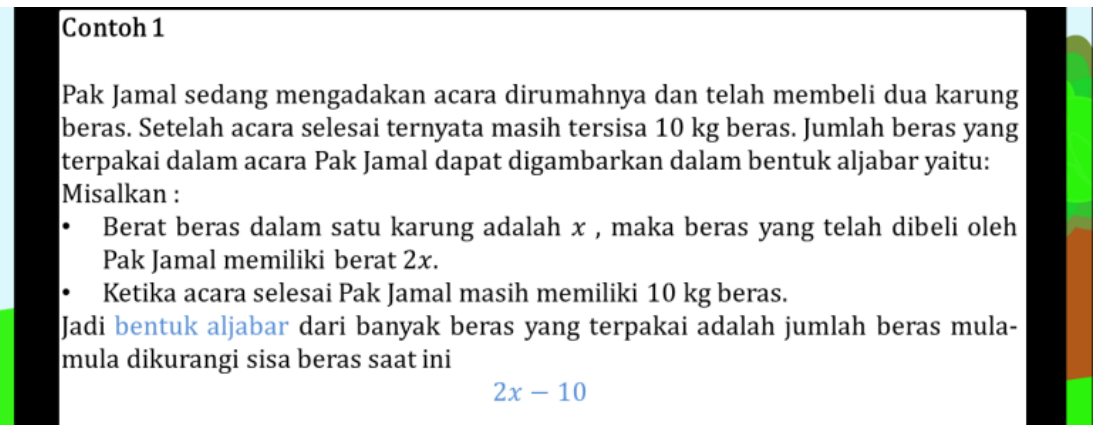

\section{Gambar 5. Tampilan Contoh Bentuk Aljabar}

Komponen reflection yaitu perenungan kembali. Pada bagian ini diberikan sebuah kegiatan menyimpulkan yang dapat dilihat pada gambar 6 berikut.

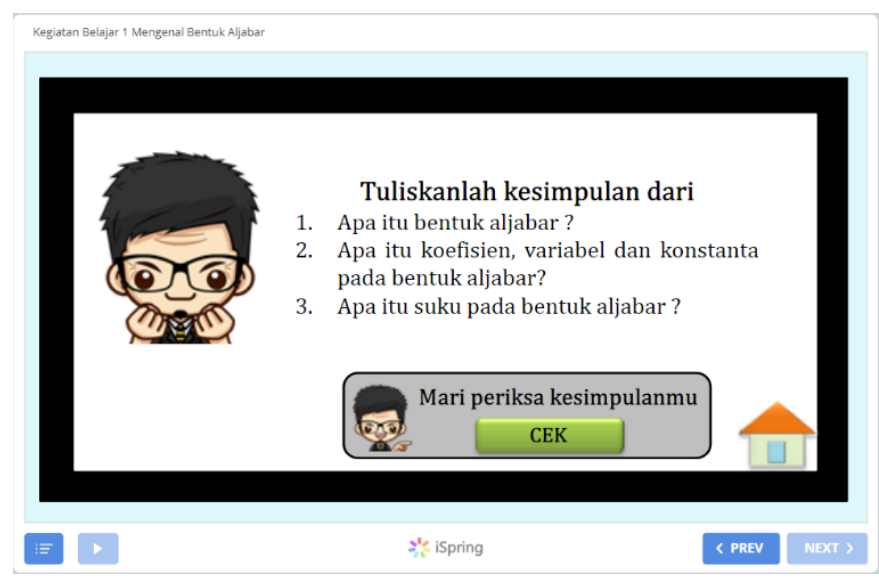

Gambar 6. Tampilan Bagian Menyimpulkan 
Komponen autentic assessment yaitu pengumpulan data yang dapat digunakan untuk melihat perkembangan siswa. Pada media pembelajaran komponen ini dimuat pada bagian latihan soal. Pada tiap kegiatan belajar setelah menyelesaikan materi akan diberikan 5 soal latihan yang harus dikerjakan siswa. Tampilan latihan soal dapat dilihat pada gambar 7 berikut.

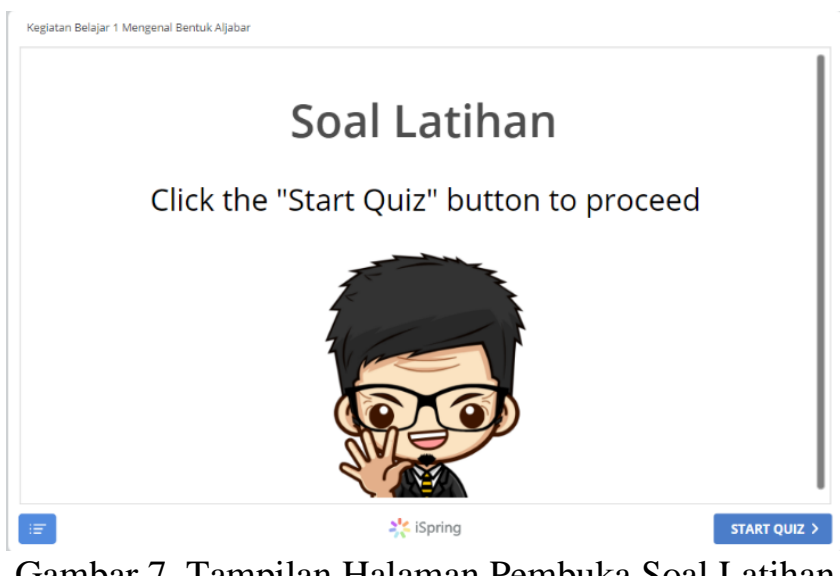

\section{Develop (Pengembangan)}

Pada tahap ini dilakukan kegiatan uji ahli untuk melihat tingkat kevalidan dari media pembelajaran dan uji coba untuk melihat kepraktisan dari media pembelajaran. Pada kegiatan uji ahli, penilaian media pembelajaran dilakukan pada komponen media dan materi. Uji ahli ini dilakukan untuk melihat tingkat kelayakan media pembelajaran sebelum digunakan untuk uji coba. Validasi yang dilakukan untuk melihat komponen media adalah penilaian pada aspek kebahasaan, aspek penyajian, aspek pengaruh media dan aspek tampilan untuk keempat kegiatan belajar. Hasil penilaian uji ahli pada setiap kegiatan belajar dapat dilihat pada tabel 3 berikut:

Tabel 3. Hasil Uji Ahli Pada Komponen Media

\begin{tabular}{|c|c|c|c|c|c|c|}
\hline \multirow[b]{2}{*}{$\begin{array}{c}\text { Kegiatan } \\
\text { Belajar }\end{array}$} & \multicolumn{4}{|c|}{ Komponen Media } & \multirow[b]{2}{*}{$\begin{array}{l}\text { Rata } \\
\text {-rata }\end{array}$} & \multirow[b]{2}{*}{ Kategori } \\
\hline & $\begin{array}{c}\text { Kebahasaa } \\
n\end{array}$ & $\begin{array}{c}\text { Penyajia } \\
n\end{array}$ & $\begin{array}{c}\text { Pengaruh } \\
\text { Media }\end{array}$ & Tampilan & & \\
\hline 1 & 4,5 & 4,1 & 4,4 & 4,1 & 4,3 & Sangat Valid \\
\hline 2 & 4,5 & 4,2 & 4,4 & 4,2 & 4,3 & Sangat Valid \\
\hline 3 & 4,5 & 4,3 & 4,4 & 4,1 & 4,3 & Sangat Valid \\
\hline 4 & 4,4 & 4,2 & 4,3 & 4,2 & 4,3 & Sangat Valid \\
\hline $\begin{array}{c}\text { Rata-rata } \\
\text { Aspek }\end{array}$ & 4,5 & 4,2 & 4,4 & 4,1 & 4,3 & Sangat Valid \\
\hline $\begin{array}{l}\text { Rata-rata } \\
\text { Komponen }\end{array}$ & \multicolumn{4}{|c|}{4,3} & & \\
\hline Kategori & \multicolumn{4}{|c|}{ Sangat Valid } & & \\
\hline
\end{tabular}

Berdasarkan hasil uji ahli oleh dosen ahli dan praktisi diperoleh rata-rata nilai yaitu 4,3. Media pembelajaran interaktif dikategorikan sangat valid. Ini menunjukkan bahwa pada komponen media, media pembelajaran yang dikembangkan layak untuk digunakan dalam kegiatan pembelajaran. 
Selanjutnya validasi yang dilakukan untuk melihat komponen materi adalah penilaian media pembelajaran pada aspek kelayakan isi, aspek kelayakan penyajian, dan penerapan pendekatan kontekstual pada keempat kegiatan belajar. Selanjutnya Hasil penilaian uji ahli pada setiap kegiatan belajar dapat dilihat pada tabel 4 berikut:

Tabel 4. Hasil Uji Ahli Pada Komponen Materi

\begin{tabular}{|c|c|c|c|c|c|}
\hline \multirow[b]{2}{*}{ Kegiatan Belajar } & \multicolumn{3}{|c|}{ Komponan Materi } & \multirow[b]{2}{*}{$\begin{array}{l}\text { Rata } \\
\text {-rata }\end{array}$} & \multirow[b]{2}{*}{ Kategori } \\
\hline & $\begin{array}{c}\text { Kelayakan } \\
\text { Isi }\end{array}$ & $\begin{array}{c}\text { Kelayakan } \\
\text { Penyajian }\end{array}$ & $\begin{array}{c}\text { Pendekata } \\
\text { n } \\
\text { Kontekstu } \\
\text { al } \\
\end{array}$ & & \\
\hline 1 & 4,3 & 4,7 & 4,3 & 4,4 & Sangat Valid \\
\hline 2 & 4,4 & 4,7 & 4,2 & 4,4 & Sangat Valid \\
\hline 3 & 4,3 & 4,7 & 4,1 & 4,4 & Sangat Valid \\
\hline 4 & 4,3 & 4,7 & 4,3 & 4,4 & Sangat Valid \\
\hline Rata-rata Aspek & 4,3 & 4,7 & 4,2 & 4,4 & Sangat Valid \\
\hline $\begin{array}{c}\text { Rata-rata } \\
\text { Komponen } \\
\end{array}$ & \multicolumn{3}{|c|}{4,4} & & \\
\hline Kategori & \multicolumn{3}{|c|}{ Sangat Valid } & & \\
\hline
\end{tabular}

Berdasarkan hasil validasi oleh dosen ahli dan praktisi diperoleh rata-rata nilai yaitu 4,4. Media pembelajaran interaktif dikategorikan sangat valid. Ini menunjukkan bahwa dari aspek materi, media pembelajaran yang dikembangkan layak untuk digunakan dalam kegiatan pembelajaran. Zakirman \& Hidayati, (2017) mengatakan bahwa media pembelajaran dikatakan valid dengan memproleh kriteria minimal valid. Sehingga media pembelajaran ini dapat diterapkan pada kegiatan uji coba. Pada kegiatan uji ahli ini, masih terdapat kesalahan dalam penulisan dan masih terdapat pemilihan kata yang kurang tepat. Validator juga mengatakan bahwa penggunaan warna pada media pembelajaran ini monoton. Oleh karena itu, peneliti melakukan revisi pada media pembelajaran dengan mengikuti saran dari validator. Media pembelajaran diterapkan dalam kegiatan uji coba setelah melalui beberapa revisi.

Kegiatan uji coba yang dilakukan dalam penelitian ini adalah uji coba one to one dan uji coba kelompo kecil. Pada kegiatan uji coba one to one ini siswa menggunakan media pembelajaran pada kegiatan belajar 1 hingga kegiatan belajar 4. Sebelum menggunakan media pembelajaran, peneliti memberikan informasi terkait media pembelajaran interaktif bentuk aljabar dan kegiatan uji coba yang akan dilakukan. Selama kegiatan uji coba oe to one peneliti bertindak sebagai pendamping dan memberikan arahan untuk membaca dan memahami setiap kegiatan belajar yang ada pada media pembelajaran. Selama kegiatan uji coba one to one siswa aktif bertanya baik mengenai cara penggunaan media dan juga mengenai materi yang terdapat didalam media pembelajaran ini.

Pada kegiatan uji coba one to one setiap siswa membutuhkan waktu yang berbeda untuk menyelesaikan setiap kegiatan belajar. Secara umum waktu yang dibutuhkan siswa untuk mengikuti setiap kegiatan belajar adalah 60 menit. Ini menunjukkan bahwa media pembelajaran ini dapat digunakan disekolah selama kegiatan belajar dengan waktu dua jam pelajaran. Setelah siswa selesai 
menggunakan media pembelajaran interaktif ini, peneliti melakukan diskusi bersama siswa untuk mengetahui apakah masih terdapat penulisan kata yang salah atau masih terdapat kalimat yang kurang jelas. Dari hasil diskusi diketahui bahwa ada penggunaan tombol yang berlebihan yaitu pada halaman kalimat pengantar. Terdapat tombol next ada dua kali. Halaman tersebut dapat dilihat pada gambar 8 berikut

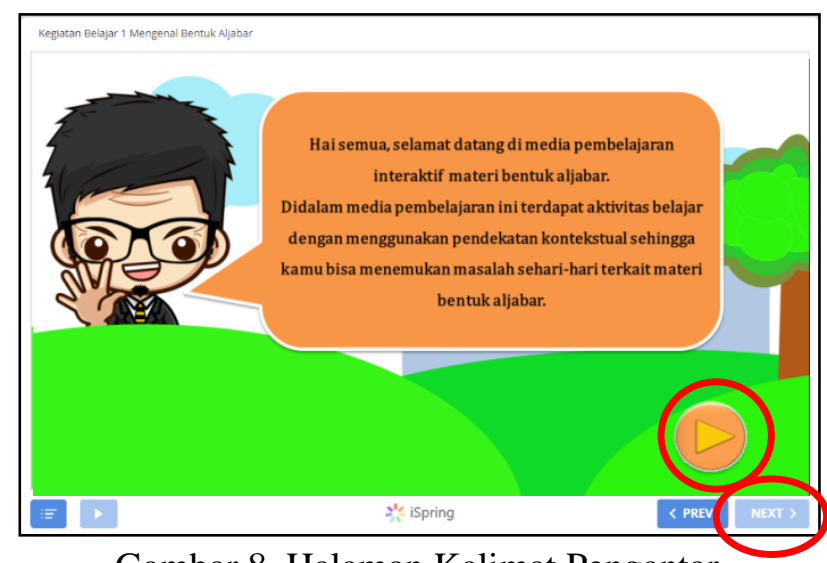

Gambar 8. Halaman Kalimat Pengantar

Dari hasil diskusi ini peneliti melakukan perbaikan terhadap media pembelajaran yaitu membuang salah satu tombol next. Hasil dari perbaikan dapat dilihat pada gambar 9 berikut

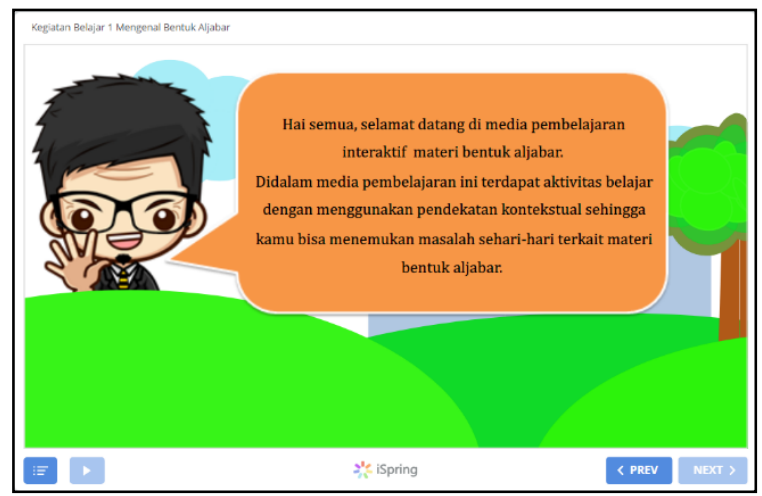

Gambar 9. Halaman Kalimat Pengantar Setelah Perbaikan

Media pembelajaran interaktif yang telah direvisi diterapkan pada kegiatan uji coba kelompok kecil untuk melihat praktikalitas dari media pembelajaran. Kegiatan uji coba kelompok kecil ini melibatkan 9 orang siswa yang dipilih langsung oleh guru dengan kriteria masing-masing tiga siswa dengan kemampuan tinggi, sedang dan rendah.

Sebelum menggunakan media pembelajaran, peneliti memberikan informasi terkait media pembelajaran interaktif bentuk aljabar dan kegiatan uji coba kelompok yang dilakukan. Selama kegiatan uji coba kelompok kecil ini, peneliti bertindak sebagai pendamping dan memberikan arahan dalam menggunakan media pembelajaran ini. Siswa menggunakan smartphone masing-masing yang yang sebelumnya telah dipersiapkan. 
Setelah selesai menggunakan media pembelajaran interaktif ini siswa diminta untuk mengisi angket respon sebagai penilaian untuk melihat praktikalitas dari media pembelajaran. Data hasil angket respon siswa dapat dilihat pada tabel 5 berikut:

Tabel 5. Hasil Uji Coba Kelompok Kecil

\begin{tabular}{|l|c|c|}
\hline \multicolumn{1}{|c|}{ Aspek } & Rata-rata & Kategori \\
\hline Aspek Pembelajaran & 4,3 & Sangat Praktis \\
\hline Aspek Tampilan & 4,4 & Sangat Praktis \\
\hline Aspek Pemograman & 4,2 & Sangat Praktis \\
\hline Rata-rata Total & $\mathbf{4 , 3}$ & Sangat Praktis \\
\hline
\end{tabular}

Berdasarkan hasil angket respon siswa pada kegiatan uji coba diperoleh nilai rata-rata untuk aspek pembelajaran 4,3, tampilan 4,4 dan pemograman 4,2. Media pembelajaran interaktif dikategorikan sangat praktis dengan rata-rata skor 4,3. Praktikalitas. Ini menunjukkan bahwa media pembelajaran yang dikembangkan mudah digunakan dan memiliki daya tarik sehingga dapat menarik motivasi belajar siswa.

Selama kegiatan uji coba Kelompok kecil peneliti melakukan diskusi dengan siswa untuk mendapatkan komentar mengenai media pembelajaran. Siswa mengatakan bahwa belajar bentuk aljabar dengan menggunakan media ini mudah untuk dipahami, contoh soal yang diberikan sederhana sehingga siswa dapat memahaminya. Tampilan media pembelajaran yang menarik dan dapat digunakan melalui smartphone membuat siswa tertarik untuk terus belajar menggunakan media ini sejalan dengan pendapat Newby (dalam Nopriyanti \& Sudira, 2015) yang mengatakan bahwa salah satu keunggulan dari penggunaan media pembelajaran intekatif adalah dapat meningkatkan motivasi belajar siswa. Pada penyajian materi diberikan animasi yang mendukung agar siswa mudah untuk memahami materi bentuk aljabar sejalan dengan fungsi media pembelajaran oleh Sumiharsono (2017) yaitu untuk memperjelas pesan agar tidak terlalu verbalistis.

\section{Disseminate (Penyebaran)}

Setelah melalui kegiatan uji ahli dan uji coba, media pembelejaran interaktif dengan pendekatan kontekstual sudah valid dan praktis. Selanjutnya dilakukan kegiatan pengemesan media pembelajaran kedalam $C D$ untuk dibagikan kepada guru dan siswa ditempat dilakukannya uji coba dan beberapa sekolah sederajat lainnya.

\section{KESIMPULAN}

Media Pembelajaran interaktif dengan pendekatan kontekstual pada materi bentuk aljabar untuk memfasilitasi motivasi belajar matematika siswa SMP telah selesai dikembangkan. Media pembelajaran ini memperoleh kriteria valid setelah melalui kegiatan uji ahli materi dan uji ahli media. Ini menunjukkan bahwa semua komponen mampu melakukan fungsi sesuai tujuan yang telah direncanakan. Media pembelajaran interaktif juga sudah melalui kegiatan uji coba one to one dan 
Pengembangan Media Pembelajaran Interaktif Dengan Pendekatan Kontekstual Pada Materi Bentuk Aljabar, Rifda Ulfa Mukhtar, Maimunah, Putri Yuanita

memperoleh kriteri praktis. Ini menunjukkan bahwa media pembelajaran dapat digunakan dan disukai dalam kegiatan pembelajaran.

\section{UCAPAN TERIMA KASIH}

Penelitian ini didukung oleh Project AKSI ADB UNRI yang menyediakan dana melalui Program Riset Penelitian Mahasiswa Tahun Anggaran 2021 untuk Rifda Ulfa Mukhtar.

\section{REFERENSI}

Abdullah, R. (2017). Pembelajaran Dalam Perspektif Kreativitas Guru Dalam Pemanfaatan Media Pembelajaran. Lantanida Journal, 4(1). https://doi.org/10.22373/lj.v4i1.1866

Aulia, F. (2014). Pengembangan media pembelajarn interaktif berbasis inkuiri untuk meningkatkan hasil belajar siswa. Chemistry in Education, 3(2).

Dwi Kusumawati, A., \& Sutriyono, S. (2018). Analisis Kesulitan Belajar Siswa Pada Materi Operasi Aljabar Bagi Siswa Kelas VII SMP Negeri 3 Salatiga. Paedagoria | FKIP UMMat, 9(1). https://doi.org/10.31764/paedagoria.v9i1.265

Fathir, M. (2015). Penerapan Model Pembelajaran Kontekstual Berbasis Hands On Activity Pada Materi Statistika Untuk Meningkatkan Motivasi Dan Hasil Belajar Siswa. Jurnal Ilmiah Mandala Education, 1(2).

Handayani, D., \& Rahayu, D. V. (2020). Pengembangan Media Pembelajaran Interaktif Berbasis Android Menggunakan Ispring Dan Apk Builder. M A T H L I N E Jurnal Matematika Dan Pendidikan Matematika, 5(1).

Hasibuan, I. (2015). Hasil Belajar Siswa Pada Materi Bentuk Aljabar Di Kelas VII SMP Negeri 1 Banda Aceh Tahun Pelajaran 2013/2014. Jurnal Peluang, 4(1).

Herutomo, R. (2017). Miskonsepsi Aljabar: Konteks Pembelajaran Matematika Pada Siswa Kelas Viii Smp. Jurnal Pendidikan Dasar, l(November).

Istiqlal, M. (2017). Pengembangan Multimedia Interaktif Dalam Pembelajaran Matematika. JIPMat, 2(1). https://doi.org/10.26877/jipmat.v2i1.1480

Karuniakhalida, P., Maimunah, M., \& Murni, A. (2019). Development of ICT-Based Mathematical Media on Linear Program Materials to Improve Motivation Learning Students. Journal of Educational Sciences, 3(2). https://doi.org/10.31258/jes.3.2.p.195-204

KOMINFO. (2017). Survey Penggunaan TIK 2017: Serta Implikasinya terhadap Aspek Sosial Budaya Masyarakat. Pusat Penelitian Dan Pengembangan Aplikasi Informatika Dan Informasi Dan Komunikasi Publik.

Nopriyanti, N., \& Sudira, P. (2015). Pengembangan multimedia pembelajaran interaktif kompetensi dasar pemasangan sistem penerangan dan wiring kelistrikan di SMK. Jurnal Pendidikan Vokasi, 5(2). https://doi.org/10.21831/jpv.v5i2.6416

Nuraisah, E., Irawati, R., \& Hanifah, N. (2016). Perbedaan Pengaruh Penggunaan Pembelajaran 
Konvensional Dan Pendekatan Kontekstual Terhadap Kemampuan Berpikir Kritis Matematis

Dan Motivasi Belajar Siswa Pada Materi Pecahan. Jurnal Pena Ilmiah, 1(1). https://doi.org/10.23819/pi.v1i1.3033

Retnasari, R., Maulana, \& Julia. (2016). Pengaruh Pendekatan Kontekstual Terhadap Kemampuan Koneksi Matematis Dan Motivasi Belajar Siswa Sekolah Dasar Kelas IV Pada Materi Bilangan Bulat. Jurnal Pena Ilmiah, 1(1). https://doi.org/10.23819/pi.v1i1.3045

Roza, Y., Yuanita, P., Saragih, S., Alfajri, H., \& Saputra, A. (2017). Computer-Based Media for Learning Geometry at Mathematics Class of Secondary Schools. JOURNAL OF EDUCATIONAL SCIENCES, 1(1). https://doi.org/10.31258/jes.1.1.p.79-91

Saefuddin, A., \& Berdiati, I. (2016). Pembelajaran Efektif. Bandung: PT. Remaja Rosdakarya.

Sugiyono. (2019). Metode Penelitian \& Pengembangan Research and Development. Bandung: Alfabeta.

Sumiharsono, R., \& Hasanah, H. (2017). Media Pembelajaran. Jawa Timur: Pustaka Abadi.

Zakirman, Z., \& Hidayati, H. (2017). Praktikalitas Media Video dan Animasi dalam Pembelajaran Fisika di SMP. Jurnal Ilmiah Pendidikan Fisika Al-Biruni, 6(1). https://doi.org/10.24042/jpifalbiruni.v6i1.592 